\title{
Analysis Of The Relationship Between Prices, Promotions, Variants Of Products And Sales Volume In Lego Brand Toy Products In Grand City Surabaya
}

\author{
Asrul Ramadhanni dan Arasy Alimudin \\ Program Studi Manajemen, Fakultas Ekonomi Dan Bisnis \\ Universitas Narotama Surabaya \\ Email author: arasyalimudin@ narotama.ac.id
}

\begin{abstract}
This study aims to analyze the relationship between price, promotion, product variants, and sales volume of Lego branded toy products at Grand City Surabaya. This research is quantitative. Population and sample based on distributing questionnaires to consumers or customers of Lego brand products in Grand City Surabaya and a sample of 100 respondents was taken. Data collection techniques are using observation, interviews, and documentation. The data analysis used was a validity test, reliability test, and chi-square test. The results showed that price, promotion, and product variants had a significant relationship with sales volume which had a significant value $<0.05$. The indicator of interest in the implementation of a promotional event from the promotional variable is the most very significant and has a significant value of 0.000 . So the variable price, promotion, and product variants have a good relationship with sales volume so that sales levels are stable and increasing.
\end{abstract}

Keyword:

Prices, Promotion, Product Variants, Sales Volume, Chi-Square Test

\section{Pendahuluan}

Persaingan dalam bisnis bukanlah sesuatu hal yang baru dalam dunia perdagangan global, terutama dalam memperebutkan pasar potensial dan mempertahankan konsumen yang ada. Perkembangan dunia usaha yang dinamis dan penuh persaingan menuntut perusahaan untuk melakukan orientasi terhadap cara mereka melayani konsumennya, menangani pesaing, dan mengeluarkan produk. Dalam hal ini perusahaan barang atau jasa yang bersangkutan dituntut jeli untuk menangkap peluang yang ada agar dapat bertahan atau semakin berkembang maju seiring dengan perubahan zaman.

Dalam keadaan yang seperti itu, peranan pemasaran sangatlah penting. Pemasaran merupakan sebuah ujung tombak bagi setiap perusahaan dan sebagai peranan yang bertanggung jawab dalam menentukan ataupun mengembangkan sebuah produk/jasa yang dimiliki perusahaan dalam menghadapi pemasaran produknya ke pasar konsumen.

Di dalam perkembangan jaman sekarang, sebuah mainan merupakan sesuatu yang digunakan dalam permainan oleh anak - anak, orang dewasa ataupun mungkin juga binatang. Berbagai keragamaman barang atau benda dibuat untuk digunakan sebagai mainan, akan tetapi barang atau benda yang telah diproduksi untuk tujuan lain dapat pula digunakan sebagai mainan. Disini misalnya, ada seorang anak yang mengambil suatu alat rumah tangga. Dan dengan imajinasinya anak tersebut 'menerbangkan' benda itu dan dilakukannya sampai mengelilingi rumahnya, membayangkannya bahwa benda tersebut yang digunakan merupakan sebuah pesawat terbang. Jenis barang lain yang dipasarkan sebagai mainan, ditujukan mungkin sebagai barang - barang koleksi dan barang barang dari jenis ini tidak umum untuk dimainkan. Berbagai jenis mainan (bahkan ribuan jenis) telah diciptakan oleh manusia, dari tahun ke tahun, bahkan setiap generasi manusia pasti memiliki jenis atau tipe mainan masingmasing.

Lego merupakan merek sebuah perusahaan yang bergerak dibidang produk mainan yang sejenis alat permainan bongkah plastik kecil yang terkenal di dunia khususnya dikalangan anak-anak atau remaja maupun juga dewasa, tidak pandang lelaki ataupun perempuan. Bongkah-bongkah ini serta kepingan lain bisa disusun menjadi model apa saja. Adapun yang lain seperti sebuah mobil, kereta api, bangunan, kota, patung, kapal, pesawat terbang, pesawat luar angkasa, serta robot, semuanya ada dan bisa dibuat. Alat permainan ini dikeluarkan oleh Perusahaan LEGO dari Denmark.

PT. Adidaya Multi Niaga adalah perusahaan yang bergerak di bidang retail dengan produk berupa mainan import yang berasal dari Denmark yaitu Lego. Perusahaan yang didirikan 9 Januari 2014 ini merupakan anak perusahaan dari PT. ALJ Tranding Indonesia, yang mana perusahaan ini sendiri adalah distributor langsung produk mainan Lego yang mewakili kawasan Indonesia, Singapura, Malaysia, dan Filiphina. 
Perbedaan penjualan dari kedua perusahaan ini adalah terletak di area penjualan, PT. ALJ Tranding Indonesia merupakan pemasok langsung bagi toko mainan retail di Indonesia seperti Kids Station, Sogo, Toys Kingdom, Seibu, Toys City dan Debenhams yang mana salah satu produk mainan yang dijual adalah Lego. Sedangkan PT. Adidaya Multi Niaga sendiri adalah khusus hanya menjual produk mainan Lego dalam satu area toko dengan koleksi yang lebih eksklusif dan limited. Perusahaan yang mempunyai empat toko cabang yaitu di Surabaya, Bali, dan dua di Jakarta.

Tujuan mengapa didirikannya PT. Adidaya Multi Niaga adalah dikarenakan produk Lego mempunyai banyak varian sehingga dibuatkan Toko khusus yang hanya menjual Lego yaitu Lego Shop. Koleksi yang dimiliki Lego Shop sangat bermacam dan variatif seperti koleksi series, lose brick, aksesoris, merchandise, sampai koleksi limited sehingga PT. Adidaya Multi Niaga berfokus meningkatkan penjualan Lego pada satu Toko. Bukan hanya digemari oleh anak-anak saja, tapi orang dewasa juga banyak yang menyukai Lego. Mainan anak ini memiliki lima nilai yang dapat dipelajari di kehidupan sehari-hari yaitu mengasah imajinasi, meningkatkan kreatifitas, menciptakan kegembiraan, menuntut anak agar belajar, menumbuhkan rasa peduli, dan meningkatkan kualitas daya pola pikir anak.

Berdasarkan uraian pada latar belakang masalah diatas, maka rumusan masalah dalam penelitian ini adalah :

1. Apakah harga mempunyai hubungan yang signifikan dengan volume penjualan Produk mainan merk Lego di Grand City Surabaya?

2. Apakah promosi mempunyai hubungan yang signifikan dengan volume penjualan Produk mainan merk Lego di Grand City Surabaya?

3. Apakah varian produk mempunyai hubungan yang signifikan dengan volume penjualan Produk mainan merek Lego di Grand City Surabaya?

\section{Tinjauan Pustaka}

\subsection{Penelitian Terdahulu}

Khaerul Satir (2015), dengan judul Pengaruh Harga Dan Promosi terhadap Peningkatan Volume Penjualan Rumah pada PT. Haji Satir di Makasar. Penelitian ini bertujuan untuk mengkaji dan menganalisis pengaruh harga dan promosi terhadap peningkatan volume penjualan dan menganalisis variabel yang dominan berpengaruh terhadap volume penjualan rumah pada PT. Haji Satir di Makassar. Penelitian ini adalah penelitian kuantitatif. Populasi dan sampel penelitian berdasarkan perolehan data selama lima tahun $(2010-2014)$ atas volume penjualan rumah, harga dan biaya promosi yang dikeluarkan. Teknik pengumpulan data menggunakan observasi dan teknik dokumentasi. Analisis data yang digunakan adalah Regresi Linier Berganda.

Ike Aris Kusumawati (2013), penelitian dengan judul Analisis Harga, Merek, Kualitas, Varian Produk terhadap Keputusan Pembelian Produk Sophie Martin untuk mengetahui pengaruh atribut produk (harga, merek, kualitas, dan varian produk) terhadap keputusan pembelian Sophie Martin secara simultan, serta mengetahui pengaruh atribut produk (harga, merek, kualitas, dan varian produk) terhadap keputusan pembelian Sophie Martin secara parsial. Data yang digunakan dalam penelitian ini berupa data primer yang diperoleh melalui penyebaran kuisioner kepada responden, yaitu member di Bussines Centre (BC) Anis Safarinda Jember. Adapun teknis pengambilan sampel yang digunakan adalah metode populasi (sensus). Untuk analisis data, penulis menggunakan analisis regresi linier berganda.

Rizky Ardiansyah (2013), penelitian ini berjudul Pengaruh Harga, Produk Dan Promosi Terhadap Volume Penjualan Sepeda Motor Honda. Penelitian ini bertujuan untuk untuk mengetahui apakah variabel harga, produk dan promosi penjualan secara parsial dan simultan memiliki pengaruh terhadap volume penjualan dan untuk mengetahui variabel manakah yang memiliki pengaruh dominan terhadap peningkatan volume penjualan sepeda motor honda pada PT. Panji Perkasa Perdana Motor Surabaya. Variabel bebas yang digunakan pada penelitian ini adalah harga, produk dan promosi penjualan, sedangkan variabel terikatnya adalah volume penjualan. Data yang digunakan adalah sekunder dengan metode pengumpulan data wawancara, observasi, dan dokumentasi. Teknik analisa data yang digunakan adalah analisa regresi berganda yang tujuannya untuk menghitung besarnya koefisien regresi yang akan menunjukkan besarnya pengaruh variabel bebas yang terdiri atas variabel harga, produk dan promosi penjualan terhadap variabel volume penjualan.

Maqfira Dwi Utami (2011), penelitian ini berjudul Analisis Pengaruh Harga dan Promosi Terhadap Peningkatan Penjualan Tiket Pada PT. Maniela Tour \& Travel di Makassar. Masalah pokok dalam penelitian ini adalah apakah harga dan promosi berpengaruh terhadap volume penjualan tiket PT. Maniela Tour \& Travel di Makassar Tujuan penelitian ini adalah untuk mengetahui sejauh mana pengaruh harga dan promosi terhadap peningkatan volume penjualan tiket pada PT. Maniela Tour \& Travel di Makassar, untuk menganalisis hubungan dan pengaruh harga dan promosi terhadap peningkatan volume penjualan tiket pada PT. Maniela Tour \& Travel di Makassar. Untuk mengaplikasikan tujuan tersebut maka digunakan metode deskriptif, metode analisis regresi linear berganda, analisis korelasi linear berganda.

Arasy Alimudin dan Habib Yoga, penelitian ini berjudul Strategi Meningkatkan Loyalitas Pelanggan pada Usaha Kecil Produk Makanan Ringan di Surabaya. Tujuan dari penelitian ini ialah membangun loyalitas 
pelanggan, karena strategi kunci mereka untuk menghadapi persaingan tersebut. Hasil analisis SWOT menunjukkan bahwa usaha kecil produk makanan ada di kuadran 4 dimana strategi yang digunakan adalah Diversifikasi dengan terus berinovasi dan memberikan berbagai terobosan dengan melakukan kombinasikombinasi keunggulan yang ada. Penelitian ini menggunakan Variabel SWOT yaitu sebagai berikut :

Variabel Kekuatan: S1 : Produk memiliki kualitas yang baik kerena berasal dari bahan yang baik, S2 :

Adanya layanan secara baik melalui sistem kekeluargaan (kemudahaan pembayaran dan pengiriman barang), S3

: Harga produk yang relatif stabil, S4 : Tidak adanya minimal order meski pelanggan merupakan reseller.

Variabel Kelemahan: W1 : Mahalnya bahan baku utama, W2 : Sedikitnya jumlah ketersediaan bahan baku utama, W3 : Kurangnya jumlah SDM produksi, W4 : Minimnya lahan produksi.

Variabel Peluang, O1 : Permintaan yang tinggi, O2 : Kepercayaan pelanggan yang besar, O3 : Pangsa pasar yang masih relatif luas, O4 : Produk yang menjadi acuan kualitas oleh produsen lain.

Variabel Ancaman, T1 : Banyaknya produsen lain yang meniru produk makanan kripik pisang, T2 : Barang subtitusi yang terus bertambah, T3 : Kesulitan bahan baku utama yang mengancam ketersediaan bahan baku di masa datang, T4 : Semakin tingginya UMK pabrik yang menyebabkan bertambah susahnya mencari SDM untuk bersedia bekerja di tingkat Usaha Kecil.

\subsection{Konsep Pemasaran}

Konsep pemasaran bertujuan untuk memberikan kepuasan terhadap keinginan dan kebutuhan pembeli atau konsumen. Seluruh kegiatan dalam perusahaan yang menganut konsep pemasaran harus diarahkan untuk memenuhi tujuan tersebut. Kegiatan dalam konsep inti pemasaran meliputi kegiatan pada semua bagian yang ada, seperti kegiatan personalia, produksi, keuangan, serta fungsi-fungsi lain yang mengarahkan kepada pemenuhan keinginan dan kebutuhan pembeli atau konsumen.

Pada masa yang telah lalu, pemasaran lebih banyak menitik-beratkan kepada tujuan penjualan dengan biaya produksi yang seminimal mungkin. Meskipun tujuan ini sangat bermanfaat pada secara individual, tetapi tidak sesuai dengan konsep pemasaran yang saat ini. Perusahaan yang berorientasi kepada pembeli memadukan keputusan pemasaran dengan fungsi didalam perusahaan. Perusahaan yang berorientasi pemasaran biasanya bagian pemasaran mengkoordinir tugas - tugas pada bagian lain dalam perusahaan secara formal maupun informal. Hal ini menunjukkan semakin pentingnya bagian pemasaran bagi perusahaan. Sebelum mengadakan pengembangan barang baru, riset pemasaran perlu dilakukan terlebih dahulu, juga untuk keuangan harus disediakan dalam kegiatan operasional perusahaan sangat berkaitan dengan pemasaran. Dalam kegiatan pemasaran sering dijumpai dengan istilah bauran pemasaran (marketing mix). Menurut Basu Swastha(2005) dalam Susatyo Herlambang (2014:33), bauran pemasaran merupakan strategi yang menggunakan kombinasi empat variabel atau kegiatan yang merupakan inti dari sistem pemasaran perusahaan yaitu Produk, struktur harga, kegiatan promosi, dan sistem distribusi.

\subsection{Harga}

Harga merupakan salah satu unsur dari bauran pemasaran. Harga sangat penting dalam menentukan nilai suatu produk tergantung pada harganya. Banyak ahli ekonomi mengandaikan bahwa konsumen itu "siap terima harga" dan menerima harga begitu saja sebagaimana diberikan. Pemasar mengakui bahwa konsumen sering secara aktif memproses informasi harga, menginterpretasi harga dari segi perngetahuan mereka berdasarkan pengalaman membeli sebelumnya, komunikasi formal (telepon penjualan iklan dan brosur), komunikasi informal (teman,rekan, atau anggota keluarga), dan titik pembelian atau sumber online. Keputusan pembelian konsumen didasarkan pada bagaimana konsumen memehami harga dan apa yang mereka anggap harga actual sekarang - bukan harga yang ditetapkan pelanggan. Menurut Kotler dan Amstrong (2003:430) harga adalah sejumlah uang yang dibayarkan atas barang dan jasa atau jumlah nilai yang konsumen tukarkan dalam rangka mendapatkan manfaat dan memiliki atau menggunakan barang atau jasa.

Kotler (2010:74) menyatakan nilai produk ditentukan berdasarkan harganya. Pernyataan ini biasa dikenal dengan teori nilai. Menjelaskan bahwa, semakin mahal harga produk, maka semakin tinggi nilainya.

Berikut landasan teori yang digunakan untuk melihat harga bauran pemasaran. Teori nilai, teori imbalan, teori potongan dan teori keuntungan. Teori ini merupakan teori untuk memahami pentingnya harga dalam aktivitas pemasaran. Teori nilai yang dikemukakan Kotler (2010:79) pada prinsipnya merupakan teori penentuan harga produk dan jasa. Teori ini menyatakan bahwa nilai produk ataupun jasa tergantung pada harganya. Harga yang tinggi selalu sebanding dengan nilai peruntukan produk atau jasa.

\subsection{Promosi}

Promosi merupakan salah satu variabel di dalam marketing mix yang sangat penting dilaksanakan oleh perusahaan dalam pemasaran produk atau jasanya. Menurut Martin L. Bell dalam Basu Swasta dan Irawan (1990:349) promosi adalah semua jenis kegiatan pemasaran yang ditujukan untuk mendorong permintaan. Sedangkan menurut William G. Nikels dalam bukunya Basu Swasta dan Irawan (1990:349) promosi adalah arus 
informasi atau persuasi satu arah yang dibuat untuk mengarahkan seseorang atau organisasi kepada tindakan yang menciptakan pertukaran dalam pemasaran.

Kedua definisi tersebut pada pokoknya sama meskipun titik beratnya berbeda. Definisi pertama lebih menitik beratkan pada pendorongan permintaan. Sedangkan definisi kedua lebih menitik beratkan pada penciptaan pertukaran. Pertukaran akan terjadi karena adanya permintaan dan penawaran, dengan adanya permintaan akan mendorong terciptanya pertukaran. Jadi promosi merupakan salah satu aspek yang penting dalam manajemen pemasaran dan sering dikatakan sebagai proses berlanjut. Dengan promosi menyebabkan orang yang sebelumnya tidak tertarik untuk membeli suatu produk akan menjadi tertarik dan mencoba produk sehingga konsumen melakukan pembelian.

Tjiptono (2004:219) menyatakan bahwa promosi merupakan salah satu faktor penentu keberhasilan suatu program pemasaran. Betapapun berkualitasnya suatu produk, bila konsumen belum pernah mendengarnya dan tidak yakin bahwa produk itu akan berguna baginya, maka konsumen tidak akan pernah membelinya.

Menurut Boyd, Walker \& Larreche (2000:65), istilah promosi banyak diartikan sebagai upaya membujuk orang untuk menerima produk, konsep, dan gagasan. Jadi, dirancang untuk menghadirkan perusahaan dan produk-produknya kepada calon konsumen serta menyampaikan ciri-ciri produk yang memuaskan kebutuhan untuk mendorong penjualan yang pada akhirnya member kontribusi laba yang memungkinkan untuk jangka panjang.

Menurut Kotler dan Keller (2007:266) promosi penjualan ialah sebagai unsur utama dalam kampanye pemasaran yang sebagian besar dirancang untuk merangsang pembelian produk atau jasa tertentu dengan lebih cepat dan lebih besar oleh konsumen atau pedagang.

\subsection{Varian Produk}

Produk didefinisikan oleh Kotler dan Amstrong (1997:274) sebagai segala sesuatu yang dapat ditawarkan ke pasar untuk mendapatkan perhatian, dibeli, dipergunakan, atau dikonsumsi dan yang dapat memuaskan keinginan ataupun kebutuhan. Yang ditawarkan dalam produk meliputi barang fisik, jasa, orang atau pribadi, tempat organisasi ataupun ide.

Menurut Kotler dan Armstrong (2008:234) bauran produk terdiri atas keanekaragaman produk (variasi), kualitas produk (quality), rancangan produk (design), ciri-ciri produk (features), merek produk (brand name), kemasan produk (packaging), tingkat pelayanan (service), garansi (warranties), ukuran produk (size), dan pengembalian (return).

Variasi produk atau keanekaragaman produk bukanlah hal yang baru dalam dunia pemasaran, dimana strategi ini banyak digunakan oleh praktisi-praktisi pemasaran di dalam aktivitas peluncuran produknya. Variasi produk memiliki pengertian yang luas tidak hanya menyangkut jenis produk dan line produk tetapi juga menyangkut kualitas, desain, bentuk, merek, kemasan, ukuran, pelayanan, jaminan dan pengembalian yang harus diperhatikan oleh perusahaan secara seksama terhadap keanekaragaman (variasi) produk yang dihasilkan secara keseluruhan. Bisa diartikan dengan semakin bervariasinya produk yang dihasilkan, maka perusahaan juga semakin banyak melayani berbagai macam kebutuhan dan keinginan konsumen yang dituju.

Menurut kotler (2009:72) mendefinisikan variasi produk sebagai unit tersendiri dalam suatu merek atau lini produk yang dapat dibedakan berdasarkan ukuran, harga, atau suatu ciri lain. Tjiptono (2008:97) variasi produk adalah suatu unit khusus didalam suatu merek atau lini produk berdasarkan ukuran, harga, penampilan atau atribut lainnya. Berdasarkan pengertian-pengertian diatas dapat diartikan bahwa variasi produk adalah strategi perusahaan dengan menganekaragamkan produknya dengan tujuan agar konsumen mendapatkan produk yang diinginkan dan dibutuhkannya.

\subsection{Volume Penjualan}

Menurut Freddy Rangkuti (2009 : 207), bahwa volume penjualan adalah pencapaian yang dinyatakan secara kuantitatif dari segi fisik atau volume atau unit suatu produk. Penjualan merupakan tujuan utama dilakukannya kegiatan dalam perusahaan. Perusahaan dalam menghasilkan barang/jasa mempunyai tujuan akhir yaitu terjualnya barang/jasa tersebut kepada masyarakat atau konsumen. Oleh karena itu, penjualan memegang peranan penting bagi perusahaan agar produk yang dihasilkan oleh perusahaan dapat terjual dan memberikan penghasilan bagi perusahaan. Penjualan yang dilakukan oleh perusahaan bertujuan untuk menjual barang atau jasa yang diperlukan sebagai sumber pendapatan untuk menutup semua ongkos guna memperoleh laba.

Menurut Hayatun Isqo (2015), volume penjualan merupakan hasil akhir yang dicapai perusahaan dari hasil penjualan produk yang dihasilkan oleh perusahaan tersebut. Volume penjualan tidak memisahkan secara tunai maupun kredit tetapi dihitung secara keseluruhan dari total yang dicapai. Seandainya volume penjualan semakin meningkat maka semakin besar laba yang didapat.

\section{Metode Penelitian}

Penelitian ini dilakukan pada pelanggan Lego di Grand City Surabaya. Yang dilakukan dengan merumuskan hipotesis untuk menjawab masalah yang dirumuskan dalam pernyataan. Sampel yang digunakan 
100 responden, jenis data yang diperlukan (kuantitatif), metode pengambilan data (primer). Teknik pengumpulan data (observasi dan kuesioner). Uji instrument penelitian menggunakan uji validitas, uji reliabilitas, dan uji crosstab chi-square.

\section{Hasil Penelitian dan Pembahasan}

Tabel 1. Jenis Kelamin

\begin{tabular}{|c|c|c|c|c|c|}
\hline & \multicolumn{5}{|c|}{ Usia } \\
\hline & & $10-20$ tahun & $21-30$ tahun & $>31$ tahun & Total \\
\hline \multirow[t]{2}{*}{ Jenis_Kelamin } & Laki - laki & 12 & 16 & 9 & 37 \\
\hline & Perempuan & 23 & 32 & 8 & 63 \\
\hline Total & & 35 & 48 & 17 & 100 \\
\hline
\end{tabular}

Responden yang berjenis kelamin laki-laki yang berusia antara 10-20 tahun terdapat 12 orang, yang berusia 21-30 tahun terdapat 16 orang, dan yang berusia diatas 31 tahun terdapat 9 orang.

Responden yang berjenis kelamin perempuan yang berusia antara 10-20 tahun terdapat 23 orang, yang berusia 21-30 tahun terdapat 32 orang, dan yang berusia diatas 31 tahun terdapat 8 orang.

Setiap penelitian pasti membutuhkan uji validitas, dikarenakan penelitian tersebut agar bisa dikatakan valid. Hal ini merupakan yang penting karena dengan uji validitas, maka data penelitian bisa dinyatakan secara akurat dan bisa diambil kesimpulannya secara nyata. Untuk itu sangat penting bagi penelitian ini untuk mencari tahu seberapa besar nilai validitas dalam kuesioner yang digunakan di dalam penelitian ini.

Jumlah responden yang digunakan di dalam penelitian ini adalah 100 orang, maka nilai $r$ tabel dapat :

$\mathrm{df}=\mathrm{n}-2=100-2=98$

$\mathrm{R}$ tabel dicari pada signifiklan $5 \%$ dengan uji 2 sisi dan $\mathrm{n}=100$, dan disini koefisien korelasi sederhananya menjadi 0,1966 .

Jadi, jika $\mathrm{r}$ hitung $>\mathrm{r}$ tabel $(0,1966)$ maka indikator-indikator tersebut dinyatakan valid. Dan juga sebaliknya jika $r$ hitung < r tabel $(0,1966)$ maka indikator-indikator tersebut dinyatakan tidak valid.

Pembuktian validitas variabel Harga (X1), Promosi (X2), Varian Penjualan (X3) dan Volume Penjualan (Y) dapat dilihat melalui tabel-tabel sebagai berikut :

\subsection{Uji Validitas}

Tabel 2. Uji Validitas

\begin{tabular}{|c|c|c|c|c|}
\hline \multicolumn{5}{|c|}{ Item-Total Statistics } \\
\hline & $\begin{array}{c}\text { Scale Mean if Item } \\
\text { Deleted }\end{array}$ & $\begin{array}{c}\text { Scale Variance if Item } \\
\text { Deleted }\end{array}$ & $\begin{array}{l}\text { Corrected Item-Total } \\
\text { Correlation }\end{array}$ & $\begin{array}{l}\text { Cronbach's Alpha if } \\
\text { Item Deleted }\end{array}$ \\
\hline $\mathrm{X} 1.1$ & 51.41 & 24.386 & .232 & .858 \\
\hline $\mathrm{X} 1.2$ & 50.87 & 21.710 & .600 & .836 \\
\hline $\mathrm{X} 1.3$ & 50.92 & 22.438 & .499 & .843 \\
\hline $\mathrm{X} 1.4$ & 50.78 & 22.133 & .577 & .838 \\
\hline $\mathrm{X} 1.5$ & 50.86 & 21.899 & .537 & .840 \\
\hline $\mathrm{X} 2.1$ & 50.79 & 23.521 & .428 & .847 \\
\hline $\mathrm{X} 2.2$ & 50.77 & 22.401 & .544 & .840 \\
\hline $\mathrm{X} 2.3$ & 50.65 & 23.402 & .425 & .847 \\
\hline X3.1 & 50.68 & 22.179 & .583 & .838 \\
\hline X3.2 & 50.64 & 22.677 & .543 & .840 \\
\hline X3.3 & 50.67 & 21.779 & 617 & .835 \\
\hline X3.4 & 50.64 & 23.324 & .456 & .845 \\
\hline $\mathrm{Y}$ & 51.64 & 20.798 & .583 & .838 \\
\hline
\end{tabular}

Sumber : output SPSS 16.0

Pada tabel di atas bisa dilihat bahwa data pernyataan pada kuisioner dinyatakan valid karena nilai koefisien korelasi ( $\mathrm{r}$ hitung) lebih besar dari nilai kritis ( $\mathrm{r}$ tabel). Oleh karena itu bisa dikatakan bahwa alat ukur untuk mengukur penelitian ini dapat dipenuhi dan valid. Jadi, kuisioner ini bisa diajukan kepada responden 
untuk mengukur apa yang akan diukur di dalam penelitian ini. Dan kuisioner ini bisa memberikan data yang dibutuhkan oleh penelitian ini.

\subsection{Uji Reliabilitas}

Reliabilitas adalah sesuatu instrumen yang dapat dipercaya untuk digunakan sebagai alat pengumpul data karena instrumen tersebut sudah baik dan terpercaya (Arikunto, 2010). Uji ini cukup penting karena instrumen yang baik dan reliabel maka akan menghasilkan data yang terpercaya, jika data sudah reliabel maka data mampu mengungkap data yang dibutuhkan oleh penelitian dan data tersebut sudag terpecaya dan dapat dibuktikan kebenarannya. Untuk itu, di bawah ini akan ditampilkan hasil nilai reliabilitas penelitian ini :

\begin{tabular}{|c|c|}
\hline $\begin{array}{c}\text { Cronbach's } \\
\text { Alpha }\end{array}$ & $\mathrm{N}$ of Items \\
\hline .853 & 13 \\
\hline
\end{tabular}

Menurut Sugiyono (2012) suatu instrumen dapat dinyatakan reliabel jika koefisien reliabilitas minimal 0.60. Maka bisa dikatakan jika cronbach alpha di bawah 0.60 maka data dinyatakan tidak reliabel dan sebaliknya jika cronbach alpha di ats 0.60 maka data dinyatakan reliabel. Dan bisa dilihat bahwa di tabel tersebut, data penelitian ini mempunyai cronbach alpha .853 dan berada di atas 0.60 , maka data penelitian ini dapat dinyatakan reliabel dan dapat dipercaya.

\subsection{Uji Chi - Square}

Tujuan yang paling utama dari penelitian ini adalah untuk menganalisi dan mengukur hubungan antara variabel Harga (X1), Promosi (X2), Varian Produk (X3) dan variabel Volume Penjualan (Y). Proses pengolahan data akan memakai analisis Crosstab Chi-Square Tests. Hasil analisis (outpout) dari pengolahan data Crosstab Chi-Square Tests dapat dilihat pada tabel berikut ini :

Tabel 4. Uji Chi

\begin{tabular}{cc}
\hline Indikator & Nilai \\
\hline $\mathbf{X}_{\mathbf{1 . 1}}$ & .027 \\
$\mathbf{X}_{\mathbf{1 . 2}}$ & .007 \\
$\mathbf{X}_{\mathbf{1 . 3}}$ & .002 \\
$\mathbf{X}_{\mathbf{1 . 4}}$ & .002 \\
$\mathbf{X}_{\mathbf{1 . 5}}$ & .012 \\
$\mathbf{X}_{\mathbf{2 . 1}}$ & .000 \\
$\mathbf{X}_{\mathbf{2 . 2}}$ & .002 \\
$\mathbf{X}_{\mathbf{2 . 3}}$ & .006 \\
$\mathbf{X}_{\mathbf{3 . 1}}$ & .005 \\
$\mathbf{X}_{\mathbf{3 . 2}}$ & .005 \\
$\mathbf{X}_{\mathbf{3 . 3}}$ & .048 \\
$\mathbf{X}_{\mathbf{3 . 4}}$ & .001 \\
\hline \multicolumn{2}{c}{ Data olahan dari SPSS 16.0 } \\
\hline
\end{tabular}

Hubungan antara harga terjangkau (X1.1), harga sesuai kualitas (X1.2), harga cukup bersaing (X1.3), harga sesuai manfaat (X1.4), harga mempengaruhi minat beli (X1.5) dengan tingkat pembelian pelanggan (Y1) bisa dikatakan signifikan berhubungan karena nilai koefisien mempunyai hasil $<0,05$.

Hubungan antara ketertarikan pelaksanaan event promosi (X2.1), kemudahan mencari informasi melalui internet (X2.1), papan nama toko menarik (X2.3) dengan tingkat pembelian pelanggan (Y1) bisa dikatakan signifikan berhubungan karena nilai koefisien mempunyai hasil $<0,05$.

Hubungan antara produk mempunyai kualitas (X3.1), design produk menarik (X3.2), produk mempunyai bentuk yang unik (X3.3), kemasan mempengaruhi minat beli (X3.4) dengan tingkat pembelian pelanggan (Y1) bisa dikatakan signifikan berhubungan karena nilai koefisien mempunyai hasil $<0,05$.

\section{Penutup}

Berdasarkan pada tujuan penelitian mengenai hubungan antara Harga, Promosi, Varian Produk dengan Volume Penjualan yang dilakukan pada konsumen atau pelanggan yang membeli produk mainan Lego di Grand City Surabaya maka ditarik beberapa kesimpulan sebagai berikut :

1. Harga (X1) yang terdiri dari harga terjangkau (X1.1), harga sesuai kualitas (X1.2), harga cukup bersaing (X1.3), harga sesuai manfaat (X1.4), dan harga mempengaruhi daya beli (X1.5) merupakan variabel yang 
mempunyai hubungan yang signifikan dengan Volume Penjualan (Y) terdapat nilai signifikan $<0,05$ dan yang paling sangat signifikan ialah harga cukup bersaing (X1.3) dan harga sesuai manfaat (X1.4) yang mempunyai nilai signifikan sebesar 0,002.

2. Promosi (X2) yang terdiri dari ketertarikan pada pelaksanaan event promosi (X2.1), kemudahan mencari informasi melalui internet (X2.2), dan ketertarikan pada papan nama toko (X2.3), merupakan variabel yang mempunyai hubungan yang signifikan dengan Volume Penjualan (Y) yang terdapat nilai signifikan $<0,05$ dan yang paling sangat signifikan ialah ketertarikan pada pelaksanaan event promosi (X2.1) yang mempunyai nilai signifikan sebesar 0,000 .

3. Varian Produk (X3) yang terdiri produk mempunyai kualitas (X3.1), design produk menarik (X3.2), produk mempunyai bentuk yang unik (X3.3), dan kemasan produk mempengaruhi daya beli (X3.4) merupakan variabel yang mempunyai hubungan yang signifikan dengan Volume Penjualan (Y) yang terdapat nilai signifikan < 0,05 dan yang paling sangat signifikan ialah kemasan produk mempengaruhi daya beli (X3.4) yang mempunyai nilai signifikan sebesar 0,001 .

Dari uraian tersebut diatas diantara ketiga variabel yang mempunyai nilai hubungan paling tinggi adalah ketertarikan pada pelaksanaan event promosi sehingga dapat diartikan bahwa apabila pada pelaksanaan event promosi lebih diperhatikan maka volume penjualan akan semakin meningkat dan apabila pada pelaksanaan event promosi tidak dilakukan maka volume penjualan tidak akan stabil atau dikatakan menurun.

Berdasarkan hasil penelitian di atas, saran - saran bisa dijadikan sebagai berikut :

1. Bagi Perusahaan

Bagi perusahaan produk merek Lego di Grand City supaya untuk mempertahankan nilai atau keunggulan yang sudah dimiliki untuk meningkatkan Volume Penjualan, karena Harga, Promosi dan Varian Produk mempunyai hubungan yang baik pada Volume Penjualan agar tingkat penjualan selalu meningkat.

2. Bagi peneliti lain

Mengadakan penelitian lanjut dengan permasalahan yang sama, namun dengan variabel lain yang ada hubungannya pada Volume Penjualan.

\section{Daftar Pustaka}

Alimudin, Arasy dan Habib Yoga.2015. Strategi Meningkatkan Loyalitas Pelanggan pada Usaha Kecil Produk Makanan Ringan di Surabaya.Jurnal Dosen Fakultas Ekonomi dan Bisnis Universitas Narotama.

Ardiansyah, Rizky.2013. Pengaruh Harga, Produk, Dan Promosi Terhadap Volume Penjualan Sepeda Motor Honda.Surabaya.Jurnal Ilmu dan Riset Manajemen.

Arikunto.2010.Prosedur penelitian "Suatu pendekatan praktik" (edisi revisi).Jakarta.Rineka Cipta

Boyd, W.Harper, Orville C. Walker dan Jean-Claude Larreche.2000. Manajemen Pemasaran "Suatu pendekatan Strategis dengan Orientasi Global".Jakarta.Erlangga.

Dwi Utami, Maqfira.2011. Analisis Pengaruh Harga Dan Promosi Terhadap Peningkatan Penjualan Tiket Pada Pt. Maniela Tour \& Travel Di Makassar.Skripsi.

Herlambang, Susatyo SE. MM.2014. Dasar-dasar Pemasaran "Cara Mudah Memahami Ilmu Pemasaran".Yogyakarta.Gosyen Publising.

Isqo, Hayatun.2015. Pengaruh Variasi Produk terhadap Volume Penjualan merek AKO pada Matahari Dept. Store Lembuswana di Samarinda.eJournal Ilmu Administrasi Bisnis.

Kotler, Philip dan Amstrong,Gary.1997. Dasar-dasar Pemasaran "Principles of Marketing 11 $\neg \neg \neg \neg$ th edition" Jilid 2 Edisi Bahasa Indonesia. Jakarta.Prenhallindo.

Kotler, Philip dan Gary Amstrong.2003. Dasar-dasar Pemasaran jilid 1 Edisi Kesembilan.Jakarta.PT.Indeks.

Kotler, Philip dan Gary Amstrong.2008. Prinsip-prinsip Pemasaran Jilid2.Jakarta.Erlangga.

Kotler, Philip dan Keller,K.L.2007. Manajemen Pemasaran edisi ke12 jilid 2 "Marketing Management" edisi Bahasa Indonesia. PT.Indeks.

Kotler, Philip.2009. Manajemen Pemasaran Jilid 9.Jakarta.PT.Prenhallindo

Kusumawati, Ike Aris.2013. Analisis Harga, Merek, Kualitas, Varian Produk Terhadap Keputusan Pembelian Produk Sophie Martin.Jember.Studi Kasus pada Business Centre.

Rangkuti, Freddy.2009. Strategi Promosi yang Kreatif, edisi pertama, cetakan pertama.Jakarta.Gramedia Pustaka

Satir, Khaerul.2015. Pengaruh Harga dan Promosi terhadap Peningkatan Volume Penjualan Rumah pada Pt. Haji Satir.Kota Makassar.Skripsi.

Sugiyono.2012.Memahami penelitian kualitatif.Bandung.Alfabeta

Swastha, Basu dan Irawan .1990. Manajemen Pemasaran Modern. Yogyakarta.Liberty.

Tjiptono, Fandy.2004. Strategi Pemasaran.Yogyakarta.Penerbit Andi. 